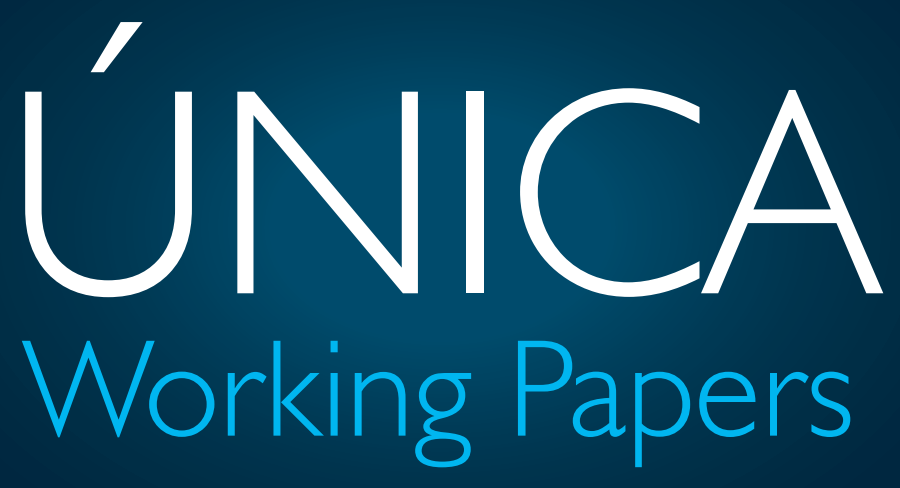

\title{
THE INCLUSION OF HISTORY IN THREE BILINGUAL PROGRAMS IN COLOMBIA (20|3-20|8)
}

- JULIO BERNAL - 


\section{THE INCLUSION OF HISTORY IN THREE BILINGUAL PROGRAMS IN COLOMBIA (2013-2018)}

Julio Bernal

Institución Universitaria Colombo Americana ÚNICA 
Facultad de Educación

Programa de Licenciatura en Bilingüismo con Énfasis en Español e Inglés

Bogotá D.C.

2018

Reg. SNIES: 106242

Vigilada MinEducación

Working Paper - Resultado de Investigación

Grupo de Investigación Innovation on Bilingual Education - INNOBED Categoría B Colciencias

Dirección de Investigaciones

Calle 19 No. $2^{\mathrm{a}}-49$, Piso 3

Centro Colombo Americano

Teléfono: 2811777 Ext. 1291

dir.investigaciones@unica.edu.co

DOI: https://doi.org/10.26817/paper.04

Prohibida la reproducción parcial o total de esta obra sin autorización de la Institución Universitaria Colombo Americana - ÚNICA 


\title{
La inclusión de la historia en tres programas bilingües en Colombia (2013-2018)
}

\section{Resumen.}

Esta investigación buscó analizar la forma en que se ha enseñado la historia en tres programas de educación bilingüe en Colombia entre 2013 y 2018. El objetivo fue discernir la metodología de la enseñanza de la historia en tres programas de educación bilingüe en Colombia. La propuesta ayudó a promover la discusión sobre la metodología que se ha utilizado en la enseñanza de la historia dentro de tres programas bilingües de pregrado en Colombia durante los últimos cinco años. El principal objetivo fue comprender los usos de incluir clases de historia como parte del plan de estudios para programas de educación bilingüe. Además, si hay beneficios en la inclusión de clases de historia, esta propuesta intenta documentar estos beneficios y las técnicas aplicadas en este tipo de clases. Finalmente, es necesario tomar en consideración los propósitos principales del uso de la historia en la construcción del contexto social y las habilidades de ciudadanía de los futuros maestros bilingües. También fue importante desafiar el uso de representaciones sociales en algunos de los programas bilingües de tres universidades colombianas.

Palabras clave. Conexión emocional; aportación auténtica; cultura; habilidades lingüísticas; ciudadanía; conciencia social; habilidades de pensamiento crítico.

\section{The Inclusion of History in Three Bilingual Programs in Colombia (2013-2018)}

\begin{abstract}
.
This research sought to analyze the way in which history has been taught in three bilingual undergraduate education programs in Colombia between 2013 and 2018. The objective was to discern the methodology of teaching history. The proposal helped to promote discussion about the methodology that has been used in the teaching of history within three bilingual undergraduate programs in Colombia during the last five years. The main objective was to understand the uses of including history classes as part of the curriculum for bilingual education programs. In addition, if there are benefits in the inclusion of history classes, this proposal attempts to document these benefits and the techniques applied in this type of class. Finally, it is necessary to take into consideration the main purposes of the use of history in the construction of the social context and the citizenship skills of the future bilingual teachers. It was also important to challenge the use of social representations in some of the bilingual programs of three Colombian universities.
\end{abstract}

Keywords: Emotional connection, authentic input, culture, language skills, citizenship, social awareness, critical thinking skills.

\section{A inclusão da história em três programas bilíngues na Colômbia (2013-2018)}

\section{Resumo.}

Esta pesquisa procurou analisar a maneira pela qual a história foi ensinada em três programas de educação bilíngüe na Colômbia entre 2013 e 2018. O objetivo era discernir a metodologia do ensino de história em três programas de educação bilíngüe na Colômbia. A proposta ajudou a promover a discussão sobre a metodologia que tem sido usada no ensino de história dentro de três programas bilíngues de graduação na Colômbia durante os últimos cinco anos. O objetivo principal foi compreender os usos da inclusão de aulas de história como parte do currículo dos programas de educação bilíngüe. Além disso, se houver benefícios na inclusão de aulas de história, esta proposta tenta documentar esses benefícios e as técnicas aplicadas nesse tipo de classe. Finalmente, é necessário levar em consideração os principais propósitos do uso da história na construção do contexto social 
e as habilidades de cidadania dos futuros professores bilíngües. Também foi importante desafiar o uso de representações sociais em alguns dos programas bilíngües de três universidades colombianas.

Palavras-chave. Conexão emocional; contribuição autêntica; cultura; habilidades de linguagem; cidadania; consciência social; habilidades de pensamento crítico.

\section{Une inclusion de 1'histoire dans les programmes bilingues na Colombia (2013-2018)}

\section{Résumé.}

Cette recherche visait à analyser la manière dont l'histoire a été enseignée dans trois programmes d'éducation bilingue en Colombie entre 2013 et 2018. L'objectif était de discerner la méthodologie d'enseignement de l'histoire dans trois programmes d'éducation bilingue en Colombie. La proposition a permis de promouvoir la discussion sur la méthodologie utilisée dans l'enseignement de l'histoire dans trois programmes de premier cycle bilingues en Colombie au cours des cinq dernières années. L'objectif principal était de comprendre les utilisations de l'inclusion de cours d'histoire dans le programme des programmes d'éducation bilingue. De plus, si l'inclusion de classes d'historique présente des avantages, la présente proposition tente de documenter ces avantages et les techniques appliquées dans ce type de classe. Enfin, il est nécessaire de prendre en compte les principaux objectifs de l'utilisation de l'histoire dans la construction du contexte social et des compétences citoyennes des futurs enseignants bilingues. Il était également important de contester l'utilisation des représentations sociales dans certains programmes bilingues de trois universités colombiennes.

Mots clés: Lien affectif, apport authentique, culture, compétences linguistiques, citoyenneté, conscience sociale, capacité de pensée critique.

\section{Introduction}

Including history in bilingual education programs in Colombia since 2013 has been a key element for the success of well-established bilingual programs. British and American histories, in most cases, are the type of history classes that are included in other programs. In the case of Institución Universitaria Colombo Americana (UNNICA) and Universidad Nacional de Colombia the array of history classes is diverse and it is not limited to British or American history. There are some misconceptions about the inclusion of history as field of study to promote social awareness in diverse programs that also include bilingual education. History classes in some cases are portrayed as boring because many old fashion methods are still used and some history teachers based their teaching techniques in the memorization of dates and facts that don't mean much to today's students. The idea about teachers as coaches of understanding is meaningful in the sense that teachers should not be as mere transmitters of content or activities but rather vehicles that could ensure learning. Interdisciplinary studies must be included in any field, especially in bilingual programs that focus on the teaching of future teachers. The combination of several disciplines can lead to a better understanding of global dynamics thus it can provide more knowledge and the development of language skills as a by-product. History content within bilingual programs requires the upgrading of the discipline in which interdisciplinary work can provide the needed tools that can help new bilingual teachers understanding social issues related to education. The approaches to including multi-history classes as part of upgraded bilingual programs in Colombia have taken Content and Language Integrated Learning (CLIL) and the Sheltered Instruction Observation Protocol (SIOP) models as a pedagogical component to bring together an array of rich and meaningful elements required for the development of critical thinking inside and outside the classroom. In the case of bilingual education in Colombia, some of the purposes of including history as a subject are mostly related to the development of 
social skills and the improvement of reading and writing, both in first language (L1) and second language (L2).

\section{Area of Focus Statement}

Most universities in Colombia that are offering bilingual programs are not including history in their curriculums, in their social component. For instance, in this particular study, Universidad de la Salle does not offer history classes in its social component that comprises the courses Identidad la Sallista, Humanidades I and II. In the case of the two other bilingual programs for this study, L2 acquisition and L1 are linked to the development of social awareness promoted from within the historical element. The main mission of any educator is focused as well on the promotion of civic competence and the knowledge of holistic work that can facilitate the learning process. It is believed for many academics that the new cultural approaches need to include the use of history in any field to facilitate the understanding of citizenship, politics, and society. In the teaching of languages, both L1 and L2, some bilingual education curriculums include history not only to promote social awareness, but also to improve overall language skills. Today's educational needs require the highest standards to develop a better view of the world. Still, that sole intention is not enough to address the new evolving relationship between language and new social trends that lead to the approaching of culture when learning a second language. Understanding language and culture are connected throughout interdisciplinary work. This weaving of cultural studies that includes history can promote the development of better language skills with the use of this type of content. The use of history in bilingual programs can help students to acquire language skills and social proficiency. This research analyzes the methodology used for the teaching of history within the social component for bilingual education both in ÚNICA and Universidad Nacional de Colombia.

\section{Research Questions}

Are courses in History a valuable component in building social skills, cultural appreciation and second language skills in undergraduate bilingual programs?

\section{Sub-Questions}

1. What methodologies are most effective?

2. What are the perceptions of program coordinators regarding the inclusion of history to pre-service teachers in bilingual education programs in Colombia?

\section{Theoretical Framework}

\section{Curriculum and Bilingual Programs in Colombia}

The assimilation of social awareness and bilingual proficiency requires the use of language as a vehicle that can help to gauge the learning process but also the inclusion of history that can promote the advance of higher cognitive processes inside and outside the classroom. Most bilingual programs in Colombia include social components that can raise awareness in the understanding of politics, economics, culture, and education. According to the parameters established by the Ministry of Education for Bilingual Education (Program Nacional de Bilinguismo, Colombia 2004-2019), the social component includes the cultural factor involved in learning a foreign language, which intrinsically touches the core of history as a component of the culture. 


\section{Bilingüismo: MEN}

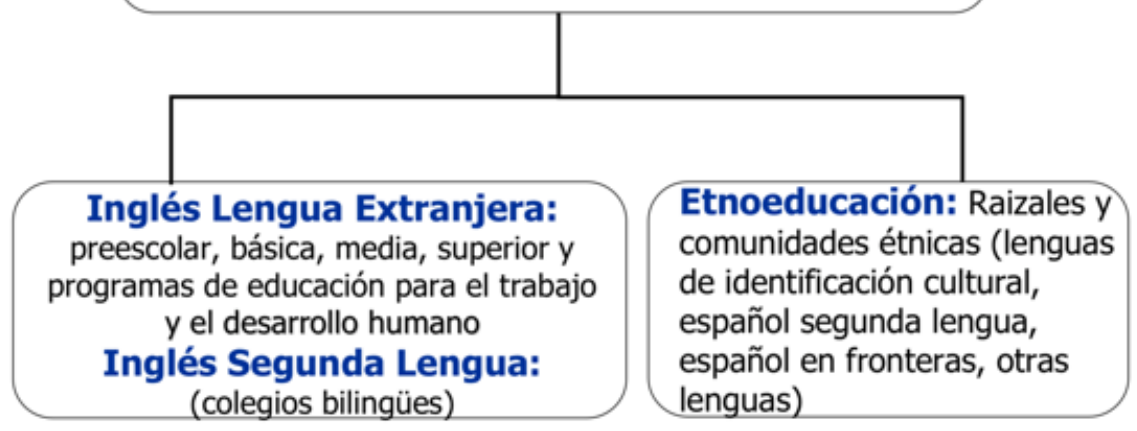

The teaching of cultural components is often related to the development of higher critical thinking and also the promotion of sense of community and citizenship (Cambridge English, 2009). History in bilingual education can promote multiple reading strategies to build meaningful vocabulary. One example that can portrait this is the analysis of primary and secondary sources such as telegrams prior to World War I where students could contextualize the cultural aspects they presented (Leingang, 2014, p.5).

In Colombia since 2014, Cátedra para la Pazincludes the following elements that make up the social component in education: a) Justicia y Derechos Humanos; b) Uso sostenible de los recursos naturales; c) Protección de las riquezas culturales y naturales de la Nación. d) Resolución pacifica de conflictos; e) Prevención del acoso escolar; f) Diversidad y pluralidad; g) Participación política; h) Memoria histórica; i) Dilemas morales; j) Proyectos de impacto social; k.) Historia de los acuerdos de paz. nacionales e internacionales; l) Proyectos de vida y prevención de riesgos. (Ley 1732 de 2014).

All these elements foster the development of social skills and can enable students to reach their learning goals.

\section{Programa Nacional de Bilingüismo}

\section{Fortalecimiento del inglés como lengua extranjera}

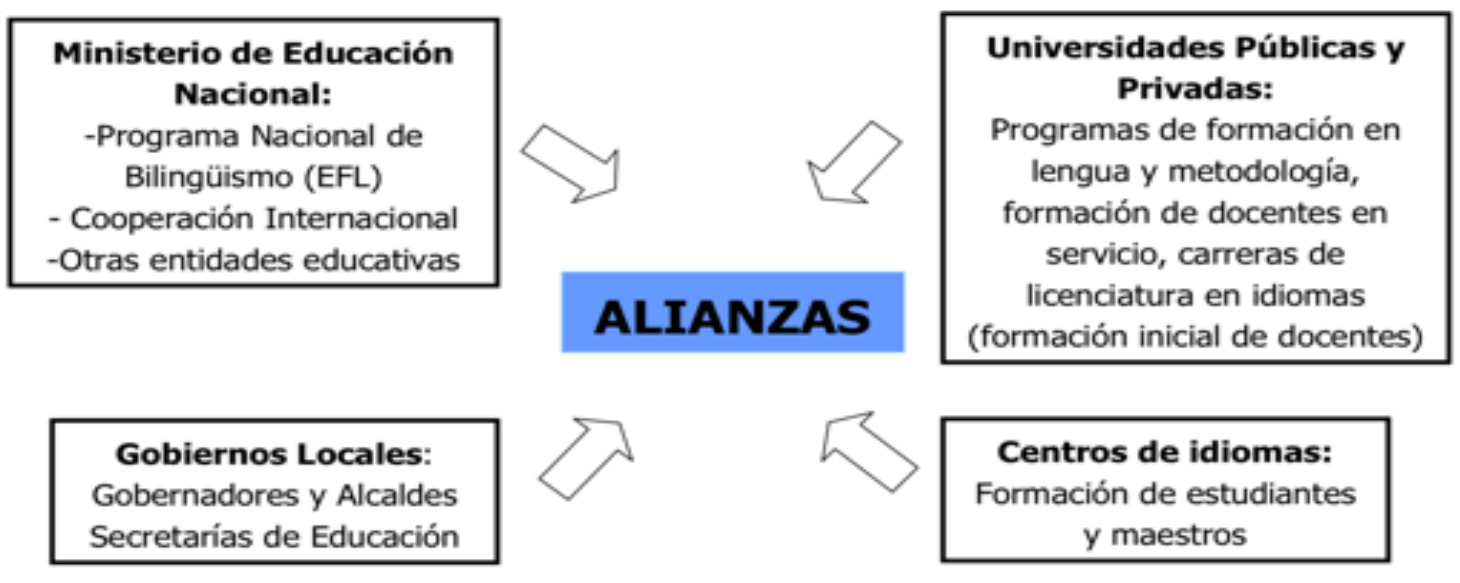

International Guidelines for Bilingual Education

Bilingual education in accordance to the guidelines from UNESCO, refers that Comparative history could create greater understanding between peoples and countries locally and globally (UNESCO, 1949; Burley and 
Dance, 1960). UNESCO guidelines include the teaching of history (local, national and global) as a component to understand cultural aspects in any proficient educational program. It is important to take advantage of the "own historical background" instead of the foreign component that in many cases is the cultural core for bilingual education.

\section{The Teaching of History}

History classes could be included in bilingual curriculums for students from across the world. History classes can be used to make connections across a range of topics in the history curriculum (Phillips, 2008). History classes provide inquiries that can promote deep and complex critical thinking thus the answers that the students bring up could be long and deep.

\section{The Didactics of history}

Many writers for history had developed different approaches to enrich the discipline. From Herodotus to Marc Bloch, the approaches of history are a reflection of cultural trends and historical periods. History methodologies involved in the development of culture and social awakening depend of other disciplines such as Geography, Anthropology, Archaeology, Art History, Economics, Sociology and even Math. Gender, culture, economics, politics, social movements and wars are a few of the key concepts that modern history includes in its approaches.

\section{Purposes in the Teaching of History}

The development of history within social sciences has evolved the most in the last two centuries. History as a part of social sciences has experienced its own revival particularly after the enlightenment movement in the XVIII century. The Greek Herodotus as one of the pioneers in field has the title of "father of history" with his work Histories. His book portraits Greek life as it was experienced first hand in the 5th century BC. The scope of his work helped the development of history as a main source for social science and it can be useful to recreate Greek society from culture to politics. One of the major topics in his work includes war and its effects among society and its own institutions such as the army and schools in general. Ever since, history has been evolving as a field of social study as the result of the general recognition that its teaching needs to have a social purpose to aid the development of general awareness and some sense of belonging. According to Canfora, the character of history through the use of periodization and the use of chronology can be represented by including a space and a temporality (Canfora, 2001, p 185).

Space and temporality play a significant part in cognition. Cognition as the corner stone of the human mental processes is responsible for connecting meaningful data that will lead to learning. History as a field of work can be used in the teaching of languages. This area can offer multiple uses that include language development. Language developments can beneficiate when students use historical approaches like oral history. Portelli (1997) states that the truth of life is in the language. In other words when humans are able to tell their stories, this exercise can lead to the enrichment of oral history as the foundation of social science. Methodologies such as Content and language-integrated learning (CLIL) and SIOP include cognition, communication, content and culture as its main components. These components can foster meaningful learning settings in any bilingual program that pursues also the development of social awareness. Also comparison is a cognitive operation (Werner \& Zimmermann, 2006, p.33).

Comparison can help with the integration of these four elements in a better setting than traditional bilingual education that only focuses on grammar lessons and language skills. One of the key features of CLIL is teacher training aimed at developing a combination of skills and competences (Cinganotto, 2013 p.1). As it was mentioned, there are some misconceptions about the approach of history as field of study using various methodologies such as CLIL or SIOP. In other words, the inclusion of history has to improve language skills 
such as reading and writing. Memorization was at one point important in education but learning history need to be significant when acquiring an L2.

In the case of oral skills, the inclusion of oral history can help in the construction of patterns of culture, social structures and historical processes (Portelli, 1997, p57). Cognitive processes are the corner stone of any bilingual program and a significant amount of social content objectives might encourage better learning experience when including cultural aspects through the use of oral history in the classroom. There is also evidence that the combination of disciplines (social science and languages) could foster better cognitive output during the development of meaningful learning related to social science. Students with outstanding social skills can be more proactive (Tilly, 2001, p 64).

\section{Social Conscience}

Language teachers who include history lessons in their practice require building a background to contextualize language concepts within culture barriers. The same background can channel students to have common cultural needs that can generate certain sense of longing or belonging. The cultural barriers from previous first hand experiences and background can interact with the new information in order to start from a point that allows them to feel identified with. Teachers may also identify the vocabulary student's need for certain cultural aspects to understand the cultural gaps to fill (Kareva-Echevarria, J. 2013). Social conscience as a by-product of history lessons is a major component for the development of citizenship proficiency that can convey positively in any bilingual program.

\section{Sense of Belonging}

Sense of belonging provides purpose and social promotion. It also fosters open communication, improves professional relations, and contributes to building trust. Sense of belonging is also the result of applying good leadership in any setting.

Leadership is a virtue that is not only needed it in military education. Leadership represents the foundation of good teaching in any level has profound implications in the promotion of competent citizenship. An educator must lead by example, therefore creating a positive environment for learning and fostering critical and creative thinking is just one of the benefits.

\section{Content Based instruction in Bilingual Education}

In Bilingual Education, the methodology of Content Based Instruction promotes the learning of the subject as the focus of the lesson. For Content Based Instruction, History lessons can fulfill the content goal helping the promotion of language learning. Content that is presented in bilingual education programs can help students acquiring better language skills, both in K12 and college level. Jong \& Harper (2005) states that the inclusion of content base lessons contribute to cultural support and the improvement of cognitive English skills implanted in bilingual education.

\section{CLIL}

In CLIL programs, cognition requires an awareness of the social environment that can be supported throughout language proficiency. CLIL promotes higher cognitive processes that are embedded in content. Also the use of various methods in the teaching of languages may facilitate the understanding of culture and the development of language skills. Szpara \& Ahmad (2007) and Jong \& Harper (2005), present two different views regarding content and cognitive processes. In both articles, the authors express their concerns about the importance of establishing a strong foundation in social studies, which includes history where language proficiency is based not only on good teaching practices, but also understanding meaningful content within the inclusion of 
background vocabulary within the learning process. Junior students that had had history classes (American history readings) both regular and special needs have seen an increase on test scores regarding to background vocabulary compared with students from previous class that does not include those readings (Leingang, 2014, p.15).

\section{Elements of CLIL}

In CLIL settings that are part of the bilingual education curriculum the use of content can be complex, but has the potential to explore emergent synergies that can give meaningful purposes to the learning process (Coyle, Hood \& Marsh, 2010, p.27). For CLIL the four elements that make up its framework are communicative, cognition, cultural elements and content. These are called the 4Cs. Ahmad \& Spara (2007) propose an approach to meet the needs of English language learners (ELLs) in CLIL classrooms that include also active participation of the community and basic communicative skills. Their approaches focus on three aspects. The first one is related to providing social and cultural support during the process of acculturation. The second is delivering explicit instruction in academic strategies that are necessary for successful comprehension of in-depth contentbase on cognitive academic language. The third aspect is reducing the cognitive load without affecting content. Communicative skills also benefit from the CLIL methodology when students develop narrative skills from historical work. Like other metaphor, however, comparisons are empty vessels, waiting for readers to endow them with meaning (Siegel, 2005, p.71). Those who engage in comparison whether they work on past or contemporary can communicate exposed to "real material" in a real context situation. In other words, twentyfirst century' students require the use of vocabulary in-context that can help them understanding the world as it is. The use of history can help improving their communicative skills with the endless array of vocabulary that can be provided in historical narrative.

Cognition plays an important role not only in CLIL, but also acquiring language skills; communicative skills are the key element in which teachers and students can verify the achievements of the learning process. In the case of including history as a field of work in bilingual education, the task and theme of oral history places the individual in social and historical context (Portelli, 1997). The concept of developing the four C's when learning history as a content-base material might help acquiring enough background vocabulary to develop social contextually and content and language skills.

Cultural elements in CLIL are embedded in the content. One example of this claim is the Harper's framework. A Framework is an attempt to democratize how we make strategic choices, how we create our future (Shemerhorn, 2002, p.298). In this case, this type of measures taken in the implementation of content that includes not only history in CLIL programs in higher education but also other social studies as geography and sociology. Framework may facilitate the development of skills that promote history awareness with some sense of democracy. Content in language integrated learning (CLIL) in English as second language (ESL) programs can help English language learners to acquire a wide range of background vocabulary to encompass the social context. In addition, the various backgrounds in communities are essential to develop language and social skills Bartik (2009).

Classes that focus on content and language can help students to develop better cognitive skills that include social proficiency. Students are more likely to learn more vocabulary and become proficient in terms of language skills and cultural adaptability. History content embedded in language material may help students to integrate civilization and culture when developing better language skills in L2. There is also the notion that learning hinges upon social interaction and takes place in a context where the knowledge or skill to be acquired is usually required or practiced (Dalton-Puffer, 2007, p. 8). 


\section{SIOP}

SIOP model is a research-based and validated instructional mold for teachers when they need to structure a class. This is composed by eight interrelated components: lesson preparation, building background, comprehensible input, strategies, interaction, practice/application, lesson delivery, and assessment. Teachers willing to perform an effective class should follow these steps when planning their lesson, teachers have to connect this model with a methodology they believe it works; besides, the SIOP Model can be applied successfully in any context where English language learners are learning content and language simultaneously.

\section{Elements of SIOP}

The SIOP is a pedagogical model that revolves around two main objectives. The inclusion of content and language objectives allows the development of skills as they progress toward fluency in the second language (Kareva-Echevarria, 2013, p. 240).

In a SIOP class, students need to interact and develop a lot more communicative skills. According to Kareva, V. \& Echevarria, J. (2013). "In SIOP classes, oral language practice helps students to develop and deepen content knowledge and support their second language speaking, reading and writing skills." For instance, in a classroom where CLIL method is used, students can talk to a partner or to a group about the topic of the day; they would use the new vocab and apply the knowledge they have just seen. In a discussion they can compare ideas and understandings of the topic.

SIOP model "addresses student learning strategies, teacher-scaffold instruction, and higher-order thinking skills" Kareva, V. \& Echevarria, J. (2013). Students need to develop cognitive tactics that they can use when $\mathrm{s} /$ he needs to solve a problem and can perform efficiently in that situation. One of the best strategies for a teacher in order to teach efficiently is scaffolding, thinking in I+1. Hence, teachers go step by step; they let students digest the new concepts they are learning. Students need to be asked with questions that challenge them more and they can think deeper.

According to Kareva, V. \& Echevarria, J. (2013). "SIOP teachers ensure that lessons include a variety of activities that encourage students to apply both the content and language skills they are learning through means such as hands-on materials, group assignments, partner work and projects." Teachers need to be very creative when designing activities that are content based. SIOP methodology also takes into account the six steps on Bloom's hierarchy in learning. The original sequence of cognitive skills is knowledge, comprehension, application, analysis, synthesis, and evaluation. Those steps can represent the learning process when content becomes meaningful to students. The use of CLIL and SIOP methodologies that include History lessons can benefit any bilingual learning environment. History as a content base element can facilitate the acquiring of better language skills, sense of belonging, student's self-steam, promotion of leadership, and the cognitive competence. These elements are essential for more complex and higher-level assignments throughout any professional career.

\section{Review of Literature}

\section{Curriculum and Bilingual Programs in Colombia}

For some researchers such as Ena Harrop, the approach of history as field of study in bilingual programs can mean that social sciences and in particular History could be a major component for the implementation of bilingual studies. According to her views, traditional teaching practices that are associated to history as content and a major part of the building of social context in bilingual students is necessary. 
Harrow also highlights, that apart from the limitations in many bilingual curriculums, there is evidence for positive outcome in the learning process when including all abilities in the teaching of subjects such as history (p. 57-70). Other writers such as Stephen Krashen (1996) mention that curriculums that have comprehensive input in the language targeted (L2) should be adapted to meet the instructional needs and learning abilities for bilingual students both in L1 and L2. Bilingual education should have a flexible and adaptable curriculum to make an everlasting impact in a potential large number of international students that are pursuing a global and international education in a wide variety of programs. For instance, International Baccalaureate programs (IB PYP, MYP and Diploma Programs) are proved to be effective as well as aligning with the Colombian National Curriculum standard (Estándares Básicos de Competencias en Lenguaje, Matemáticas, Ciencias y Ciudadanas 2006).

\section{International Guidelines for Bilingual Education}

In this particular research, the review of some written work about the impact of teaching history in bilingual education has been articulated to several elements that are mostly related to career programs in IB schools and bilingual programs. The key to understand the value of including social studies, particularly history as content is suited to local school conditions and the cultural needs of its students. Bilingual curriculum needs to include high standards for international accreditation, assessment and quality assurance (IB. 2018). The teaching of social studies that includes different types of history classes in international programs in careers and professional interests promotes the development of language skills, the building of community, critical thinking, autonomous work, self-confidence, self-awareness, resilience, flexibility, internationally-mind and global awareness (IB.2018).

Some of the benefits of including these elements are defined by the cognitive gain in students that could be attainable within the social framework present in educational programs. Comparative international education that includes social emotional skills in the cognitive goals can nurture more thoughtful individuals during the process of acquiring other languages (Balodimas, 2016, p.18). These elements are essential in bilingual programs because they can help teachers to become globally competent and also more conscious of the cognitive processes that occur in bilingual programs that are focused not only in language acquisition.

\section{History in Bilingual Education}

Some of the works reviewed for this research emphasized that it is necessary to include meaningful courses that will address the element of citizenship competency in programs that related to languages. The role of history as part of bilingual programs emphasizes that it is necessary to consider why this content provides students not only ethical values but also the development of several cognitive skills that can promote effective communication.

Therefore, understanding the purposes of including history on bilingual programs would require not only an interdisciplinary approach but also the inclusion of social skills that will allow the learning of languages, the understanding of the social context, the inclusion of ethics and the development of citizenship basic skills. Including history in the teaching process of bilingual programs becomes important not only for building social contexts either in L1 or L2, but also a major development of critical skills. Furthermore, cognitive processes related to learning acquisition and language acquisition are two different concepts; language acquisition also provides sufficiency and fluency.

In terms of including history in any language-oriented program, Hawkey (2004) offers in his research a window of opportunity to document how children use and organize historical sources. In that process, the narrative of the language appears in a natural way. Natural inquiring is one of the results of exposing children to meaningful history classes (p. 40). Allowing children to experience the value of history classes can also help them to gain self-confidence when conducting source evaluation in history lessons.

If one of goals of bilingual education is to improve social awareness, some researchers are concerned about 
lack of interest in strengthening the social content in some school programs. For instance, Margana (2003) states that it is evidenced that students will gain high English proficiency and global perspectives which are of great importance to figure out some challenges that possibly appear in global lives which demand high qualified citizens to survive in the global era. In the case of using history in bilingual classrooms, it requires the upgrading of the discipline and the inclusion of social consciousness embedded in language to improve other abilities inside and outside the classroom. This dialogue between social, philosophical and utilitarian purposes can allow the institutional evolution of the social conscience and citizenship. By wakening social consciousness within any bilingual curriculum, students can be part of the establishment of national integration and the pursuit of values that are required in the social spectrum. Ethics are an essential part in the academic field therefore the inclusion of history can help to develop moral values and a sense of a national purpose in any bilingual curriculum. The combination of disciplines (social science and languages) could improve new insights in the development of citizenship due to the fact that differences in perspectives tend to hatch strenuous tensions that allow the insights to happen (Tilly, 2001, p 64).

The teaching of history on a general level should have a purpose that should stimulate social construction. This way, the discourses of society will be embedded in social action and the benefits of learning history can be evidenced in the promotion of critical thinking skills. It is evident that citizens and institutions make their own history by supporting of history and its interaction with other social disciplines.

\section{The Didactics of History}

The idea about language teachers as coaches of understanding is meaningful in the sense that teachers shouldn't be mere transmitters of content or activities but rather vehicles that could ensure learning acquisition and better communicative skills.

The didactics of history complement the elaboration of narrative that can include ethics and social development. Kate Hawkey mentions in her work that Storytelling has always been very important for human culture and the past has always been organized and shaped through stories, complete with their neat beginnings and ends and often laden with moral purpose (Hawkey, 2007, 263).

Duignan (1998) states that foreign-born citizens and their children must be encouraged to learn the national language/second language (L2) as a way to succeed (p. 7). Interdisciplinary studies should be included in the pursuing of the learning of any second language and to acquire a L2, one has to take into consideration that this process has to be as natural as possible. In this particular case, history can ensure a natural way to facilitate the acquisition of communicative skills. However, history in language programs has been used until certain extension and the combination of several disciplines and the acquisition of an L2 can lead to a better understanding of the content of any field.

Similarly, when the focus is explicitly on inculcating a second culture, teaching the language that goes along with it has been considered a primary and necessary means to that end (Saville-Troike, 1978, p.6). The use of content in learning an L2 can facilitate not only the language proficiency but also the assimilation of the communicative means that are embedded in the crafting of languages.

\section{Development of Social Conscience and Sense of Belonging in Bilingual Programs}

Any discussion of bilingual education programs should be framed within a broader social, political, and educational context (Kerpel, Wink \& Wink, 2004). In that sense it is important to make useful the type of content that is presented in the classroom if the language goal is to create new ways of interaction that will require communicative skills.

Any teacher can give the opportunity to explore what the students learn in the classroom with role-plays and 
drills. In the case of bilingual education, the inclusion of history in the curriculum is necessary to make connections to isolate actual facts that are meaningful in the deconstruction of the social framework that students need in the actual world. However, the teaching of content objectives related to history in bilingual programs should be perceived as the main concepts teachers want students to learn.

This scaffolding can be based on the ethnic background that McAndrew (2003) proposes in her article. According to this author, schools should respect the religious beliefs of different groups and it does not imply that they would lose their responsibility to expose all students to critical knowledge, especially while teaching history, citizenship education, or cultural perspectives on religion. Thus, the minority will be exposed to values differing from those of their community of origin. Social views that include religion and culture overall are connected to language appropriation in the curriculum. These topics should be also taken into consideration when implementing pedagogical approaches.

In other words, the new approaches to history in bilingual programs must encourage students to be active participants in the whole learning process. Therefore, bilingual programs not only should include the teaching and learning of history but also have to ensure that the social structure of language acquisition has to be part of the culture objectives.

The aim of including cultural elements in bilingual programs can foster social awareness. Students from bilingual programs may see the same historical events from different points of view according to their backgrounds. In addition, the various backgrounds in communities are essential to develop a sense of belonging and active citizenship in students. Some of the reasons behind this approach assume that cultural scaffolding not only for native but also for ELLs have the potential to enrich any classroom. This scaffolding can be based on the ethnic background that McAndrew (2003) proposes in her article. According to this author, schools should respect the religious beliefs of different groups and it does not imply that they would loses their responsibility to expose all students to critical knowledge, especially while teaching history, citizenship education, or cultural perspectives on religion. Thus, the minority will be exposed to values differing from those of their community of origin. Cultural and language topics in the curriculum should also take into account pedagogical measures that will promote the implementation of methodologies such as CLIL or SIOP.

\section{Content Based instruction in Bilingual Education (CLIL and SIOP)}

Language objectives are in a way a tool of action that can make the learning measurable. CLIL and SIOP methodologies can help to acquire other culture components that are within the social framework. Intercultural communication skills, internationalization, access to subject-specific target language's terminology, language competence, oral communication skills and learner motivation are some of the elements presented in CLIL (Bartik, 2010, p.5).

Understanding how students learn in the twentieth first century requires not only an interdisciplinary work and the inclusion of ethics but also an effective planning that will include language objectives embedded in the content. Some of the practices most teachers try to implement in their students tend to always involve them in their learning process according to their own abilities and preferences. The practice of routines that keep them well informed of what is happening in the world and around them can help them gain a better understanding of social and intercultural changes.

There is another reason for using CLIL as a medium to improve and develop better skills in learners of a second language. Apart from improving their skills as critical thinkers through the use of history content for learning another language, they also can develop/improve their skills to produce the language. There is evidence about how second language learners perform better in the written production by using CLIL; they scored better at content, organization, vocabulary, language usage and mechanics (Ruiz, 2010).

The teaching of cultural objectives related to history in bilingual programs should be perceived as the main 
concepts teachers want students to learn. History must be included in the ELLs curriculum throughout the use of CLIL as a way to increase better culture and language acquisition. Critical thinking and social awareness will be the by-products to this approach. Comprehending how ELLs can learn language and cultural skills in the twentieth first century requires not only interdisciplinary work and CLIL methodology but also the understanding of the world. Students in the $21^{\text {st }}$ century will require a critical mind than can be enriched if bilingual educational programs include history as a main component of their language curriculums.

When teaching history through different pedagogical approaches such as CLIL or SIOP, it is necessary to set the goals for learners beforehand. The objectives in language and content should work intertwined to reach the students potential in accordance with the development of citizenship competences. In addition to this, learners need to encompass the whole understanding of the content to show that they are able to produce, proficiency language skills that are empowered with context that is build from social studies content. CLIL and SIOP methodologies promote attainable language goals that are meaningful according to the need needs for $21 \mathrm{st}$ Century learners. For instance, curriculums based on CLIL methodology can help learners to communicate their knowledge of historical events, chronology or descriptions in a second language; they need to discuss historical arguments and justify their opinions (Coyle, D., Hood, P. \& Marsh, D., 2010). Some bilingual programs include CLIL or other pedagogical models to foster the components of general competence such as learning to be, learning to know, learning to live together and learning to do (Granados, 2002, p. 28). Besides, the use of CLIL can show effects on students' attitudes towards English as a Foreign Language and the official language(s).

Marsh states (as cited in Lasagabaster D. \& Sierra, J., 2009) that: "CLIL programs can nurture a feel good attitude among students, it may have a positive effect on their desire to learn and develop their language competence" (Lasagabaster, D. \& Sierra J., 2009, p.5.) The acquisition of a new language depends mostly on the learner's disposition towards the target language, and the content-subject in which learners are focusing on.

Language acquisition is a subconscious process; language acquirers are not usually aware of the fact that they are acquiring language, but are only aware of the fact that they are using the language for communication (Krashen, 1987, p. 10). The building of a social background included in bilingual programs requires the incorporation of some cultural elements that are provided in international programs and career related instruction, particularly programs in foreign languages. Also language immersion is a method of teaching language, usually a second language (L2), in which the target language is used as both curriculum content and media of instruction (Pacific Policy Research Center, 2010). The inclusion of a content-based subject as history in CLIL and SIOP settings can facilitate a real immersion in the learning of a L2 and will help students in the assimilation of the social framework that is presented in any classroom setting. New teachers must take into consideration that language acquisition is a natural process through a language acquisition device that is combined to social awareness. Learning environments cannot be limited to classrooms but bilingual programs should explore other settings than can ensure a meaningful experience and the achievement of the language targets.

\section{Methodology}

This research was a case study in three different universities in Colombia. The research had a hermeneutical approach that required data collected through a database that included three data instruments. The methodology in this research had focused on three main aspects. First, the social approach in bilingual programs that seeks the understanding of society as a whole. Second, the development of language proficiency both in L1 and L2. This stage includes proficiency as a product of the inclusion of content in the development of language skills. And finally, the development of citizenship from CLIL methodology in bilingual programs. This stage fosters civic competence-the knowledge, intellectual processes and democratic dispositions required of students to be active and engaged participants in public life. The methodology of this research can also evidenced the appreciation for the richness and diversity of Colombia's heritage, both natural and cultural. 


\section{Participants}

The participants of this research were divided in three groups. Each one them belongs to the three colleges that were studied in this research. The first group was from ÚNICA. In this group there were 6 students from Latin American Contemporary History class. 4 men and 2 women, whose ages ranged between 18 to 24 years. Out of those 6 students, 2 hold full scholarships. This group thrived academically and all of the students were selfmotivated and inquisitive regardless of holding scholarships or not. For this particular class all of the students come fully prepared and have read the large amount of reading proposed for the class. The group was homogeneous in terms of attitude and behavior, but everyone constructs the class according to their different social background. There are two students who work in this group. One holds a part-time job as an English teacher and another works full time in a restaurant chain as a manager. This class is one of the four that the students will take during their under graduate studies in ÚNICA. The learning needs include the sense of purpose for their studies and their role not only as future teachers, but also as citizens of the world. One of the characteristics of UNICA'S students is their desire for constant update in the new teaching techniques. Cognition in the curriculum is always a source for innovation. The students in ÚNICA are active participants in their classes. There is also a great sense of belonging for the school and most of the students feel proud of their institution. This college has placed high importance on the wellbeing of its students and professors. It is probably one of the few schools in Colombia that has dormitories off campus for students who are not from Bogotá and lack the resources to have their own place.

The second group belongs to Universidad Nacional de Colombia. This program had 308 students (as in January $25^{\text {th }}, 2018$ ). The purpose of this program is to integrate language skills to educational proficiency in a cultural challenged world. According to the program objectives found in the Universidad Nacional de Colombia website (2018), students of the foreign language program should research about their own teaching practice. Also they may try to understand the complex social fabric thus providing solutions for the education challenges. The students from Universidad Nacional de Colombia should reflect upon aspects of language, pedagogy, and culture. The group observed was composed by 6 students that were enrolled in the foreign language program. These students were taking history classes as elective courses and the class observed was Contemporary History III, Europe since 1945. This class had 26 students that included the six students from the foreign language program. The ages of the students were from 18 to 36 years old in the whole class. The ages of students from the language program ranked between 21 to 27 years old. The class observed meets once a week and lasted for three hours.

The third group from the research was Universidad de la Salle. This school was established, oriented and directed by the Brothers of the Christian Schools Universidad de la Salle website (2018). It offers academic programs of higher education, conducts research with relevance and social impact, and also works socially with the aim of promoting the dignity and the integral development of the students. Some of the values of the school included the transformation of society, the promotion of culture and the search for the truth. Universidad de la Salle has eight faculties that constitute 23 undergraduate academic programs, 16 specialization programs and 5 master's degrees and 2 doctorates. It has 14,490 students enrolled in undergraduate programs and 700 graduate students. For this school, three interviews were conducted, since they do not offer any history classes at all. The interviews included the head of the departament of Identidad la Sallista, the assistant for the school research and one professor from Identidad la Sallista instruction. These courses do not address any type of history (Colombian or Western Civilization History).

\section{Data Collection Instruments (Syllabi, lesson plans, curriculums, textbooks).}

The purpose of reviewing this material is to find clues about the nature of the historical element that is part of the bilingual program. These documents as a whole will allow identifying the academic core of the inclusion of history as a subject in these three bilingual programs. Curriculum, Syllabi, lesson plans, and textbooks need to be reviewed to integrate them to the context of this research. This instrument will allow understanding the 
history programs in each of the three colleges in which this research took place. The documents that were analyzed are the primary source to understand the core of including history classes in bilingual programs if they had included any. The documents are public and that facilitates the interpretation of data in the time frame given. The analysis of documents is perhaps the most important instrument in this research. Each of the schools has a specific approach for including history lessons in their social component. Bilingual education in Colombia is to say the least, a recent development in the academic field. Therefore, the implementation of a social component could be based on language objectives and content objectives. The two components are essential to help developing Cognitive Academic Language Proficiency (CALPS) in the students.

\section{Interviews to coordinators and history professors from bilingual programs}

Interviews are a variety of methods of data collection in qualitative research, including observations, textual or visual analysis (e.g. from books or videos) and interviews (Silverman, 2000). In addition to that, Interviews are excellent instruments for qualitative research, due to fact that they allow participants to express themselves without being "experiences unconstrained by any perspectives of the researcher or past research findings" (Creswell, 2012).

In this case, a semi-structured interview is the most appropriate type for the data. A semi-structured interview is less rigid and the interviewer will feel more comfortable to broaden his/her answers (Brite, 1999). Semistructured interviews consist of several key questions that help to define the areas to be explored, but also allow the interviewer or interviewee to diverge in order to pursue an idea or response in more detail. (Brite, 1999). This instrument helped the research finding the purposes of including content classes in bilingual programs in the event of having history classes. Some of the questions that were included in the questionnaires were related to the value of including history classes in bilingual programs and the development of the social component in these programs. The focus of the interviews was to identify the key elements from the figure \# 1 that were included in the bilingual curriculums and how administrators and history professor were including them in their classes. For this study, interviews were conducted in the three bilingual programs from 2017 to 2018. The interviews were focused on administrators, professors of history and students.

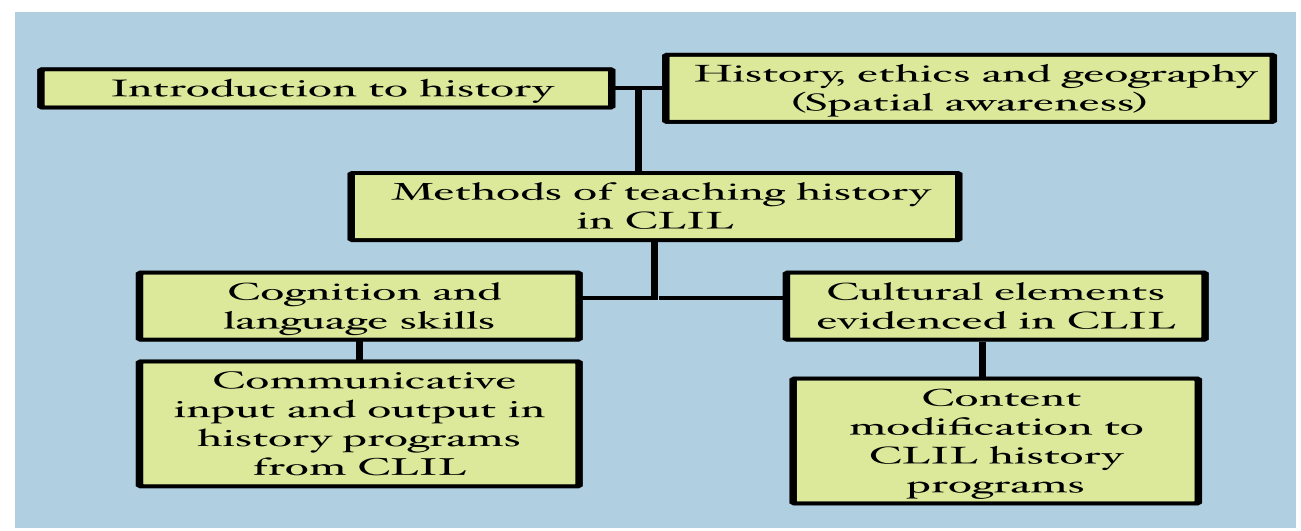

Figure 1.

Class observation in three different Colombian colleges

Observation has become a very important instrument in research. Becker and Geer $(1969,322)$ described observation as " that method in which the observer participates in the daily life of the people under study, either openly in the role of researcher or covertly in some disguised role, observing things that happen, listening to what is said, and questioning people, over some length of time". The aim of this instrument was to observe how those schools are teaching History in their bilingual programs in Colombia. Observation can help to describe the techniques history professors are using in bilingual classes. It is important to observe the 
characteristics of the classes and the minutia of what happens during instruction. This class observation instrument included the assessment of emotional support by the teacher, the organization of the classroom, the instructional support and the follow through stage. Class observation is one of the most important instruments in research because it can obtain oral and visual data and the possibility of distorting facts is minimum (Annun, 2017). Class observation was conducted from August 2017 to November 2017 in two of the three programs from this study. ÚNICA and Universidad Nacional de Colombia offer history classes in their bilingual programs. With class observation sessions, this study was able to compare the methodologies used in the schools that have history courses, the material used, and the views towards the inclusion of history from administrators, teachers and students that were taking them. In the case of Universidad de la Salle, its bilingual program does not offer any history classes.

\section{Data Analysis and Interpretation}

The data collected for this study contained document reviews, class observations and interviews for program administrators and history professors in bilingual education. The data was analyzed following guidelines for analyzing and interpreting quality data stated by Cresswell (2007, p.248). The information was gathered and organized by codes and themes. As the collected data was analyzed, the number of themes was reduced from 14 to 6 and the themes were characterized as major, minor and ordinary.

The variables mentioned were observed taking into account multiple perspectives, as history classes were not included in all three bilingual programs. The researcher was able to review a wide array of documents from each school. The documents analyzed were 22 textbooks, three curriculums from the three schools of this study, 7-history syllabus from the programs in ÚNICA and Universidad Nacional de Colombia. There were 11 interviews conducted in the schools. The interviews included the president of ÚNICA, the dean of the bilingual program 3 professors that teach history in that school, the chairman of the department of Identidad la Sallista, one professor from that program, another professor in research, and 4 professors from Universidad Nacional de Colombia.

\section{Common content themes observed in the history courses from this study}

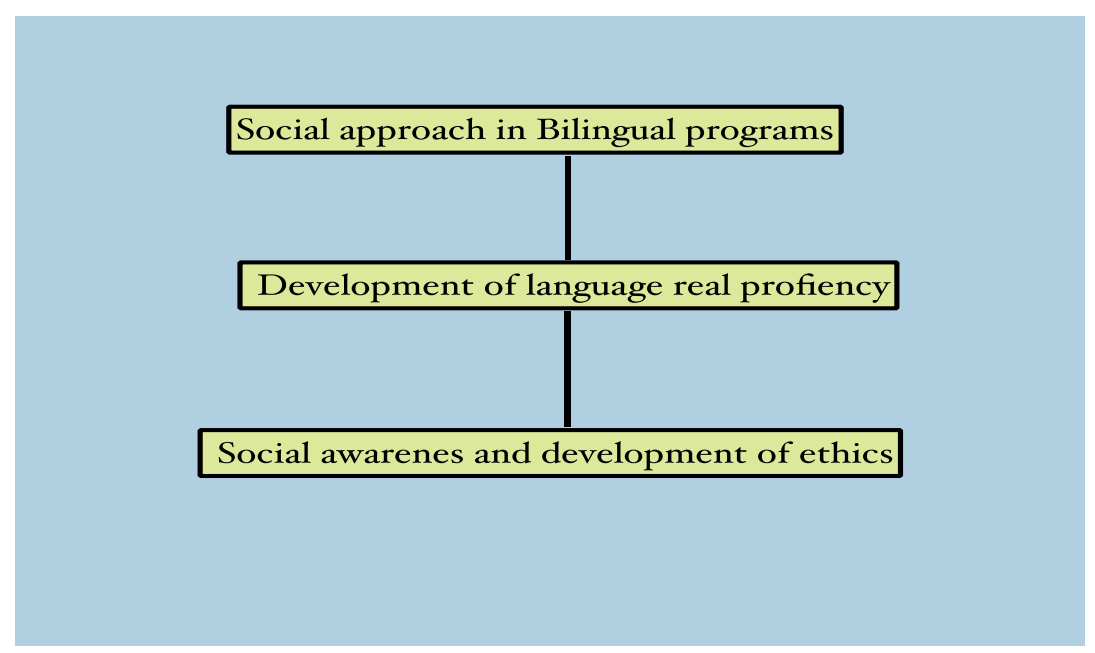

Figure 2 


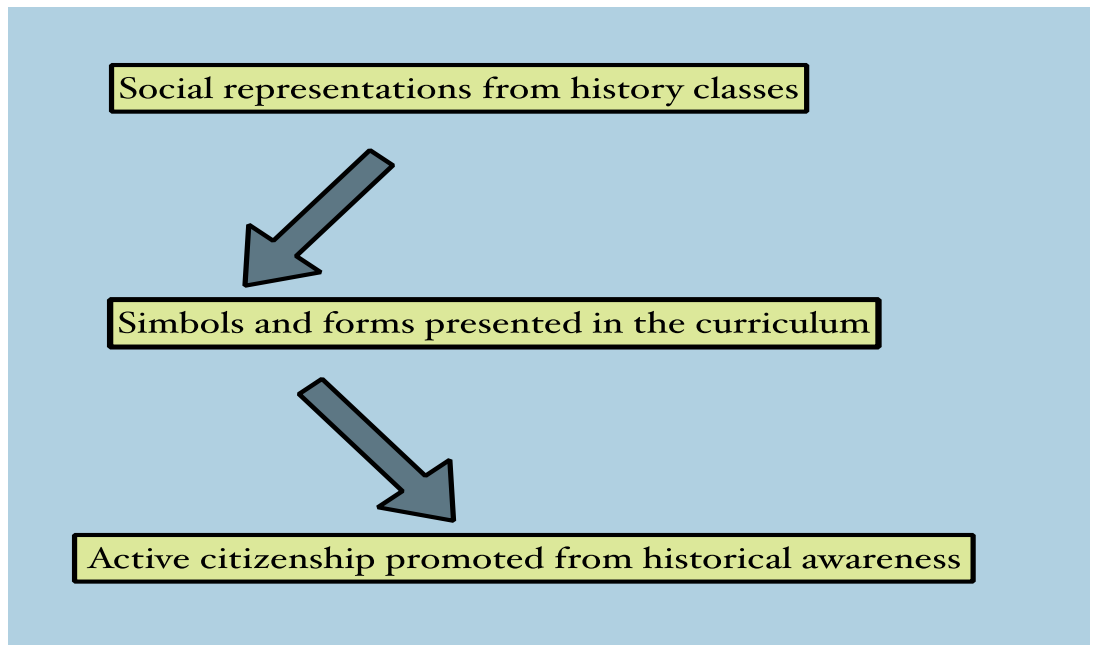

Figure 3

Each of the 6 layers contained social elements that were presented either as a topic from the curriculum or as a content goal. When conducting class observation, both in ÚNICA and Universidad Nacional de Colombia, the themes were narrowed to six main components presented in all five courses. Colombia Indigena, Latin American Contemporary History, British Civilization and History, North American Civilization and History and Contemporary History III. All these five courses promoted the understanding of history as a discipline with its methods and interpretations. Language skills development was encouraged through the use of real material such as primary and secondary historical sources. All the five professors that were observed in this study promoted the use of history as a key element to understand the present. Therefore, history classes were important to develop a sense of belonging to certain class groups. Universidad Nacional de Colombia does not offer the same courses but the history department has a very large offer in history classes. These classes included history courses in English, German, Portuguese, Italian, French and Spanish.

\section{Results}

This study intended to determine what were the pedagogical models that are being used in the teaching of history in three different bilingual programs in Colombia. UNICA and Universidad Nacional de Colombia have history classes in their bilingual curriculums. Universidad de la Salle does not include any type of history classes. The lack of history courses in Universidad de la Salle may be typical of many programs in other universities.

The pedagogical models that were observed with this study are related to CLIC and SIOP in the case of ÚNICA. In Universidad Nacional de Colombia the courses are part of the social component for the language program and they promote a communicative approach. Even though Universidad Nacional de Colombia does not uses CLIL or SIOP methodologies in their history classes and lectures, the students intrinsically evidenced the same mastering on languages and content skills both in L1 and L2. Universidad Nacional de Colombia has a wide array of different history courses that are taught not only in Spanish. The History Department offers English, German, French, and Portuguese history courses for undergraduate and graduate programs. The Department of Foreign Languages works very close with the History Department to ensure the quality of the programs and the availability for the students. A number of native professors, all with Ph.D degrees, teach their history courses in their L1 languages.

ÚNICA and in Universidad Nacional de Colombia use primary and secondary sources as written materials in the various languages. The vast readings in both programs intended to contribute to the develop language proficiency. In Universidad de la Salle's curriculum there were not history classes at all in its main social component. This component included three classes; Identidad la Sallista, Humanidades I and Humanidades II. Based 
on the three interviews conducted to administrators and teachers in this program, the analysis of the written material which included school text books and curriculum, this research could recognize that even though this program was ranked top 7 nation wide in Saber Pro 2017, the administrators do not find necessary or appealing to include history courses in its program. Another finding was that this program had three classes of Cultura Religiosa that are included in Formación la Sallista.

The perceptions of the program coordinators in ÚNICA and in Universidad Nacional de Colombia are positive regarding the inclusion of history to pre-service teachers in bilingual education. The President of UNICA strongly supports the use of history in the school bilingual program. In Universidad Nacional de Colombia the social component and the language elements (L1/L2) are closely related. The interviews with four professors who teach history classes evidenced the commitment to use the courses to strength the social component in the students who pursue a teaching career.

In the case of Universidad de la Salle, the interviews with school administrators (The chairman of Identidad la Sallista and one professor from that department) unveiled that this program included in its social component contemporary topics related to Colombia. The chairman of the department told in his interview "the program does not focus in the past, but rather in the present". Sadly for this school, "history really does not matter".

The history component in ÚNICA had four history classes. Each of the history classes counts for three (3) credits, except for Colombia Indigena that had 2 credits.

In all of the classes it was expected to develop language skills at least a B2 level, both in English and Spanish. All the history courses in this program included course projects, oral presentations, reading and writing assignments, and research.

From the data analyzed, the school promoted its students to use history as a content-based component to develop all language skills in both L1 and L2. The data also showed that history courses in this school employs a variety of teaching techniques that include hands on projects, field trips, analysis of historical sources, microteaching sessions, reading/ writing assignments and multimedia. It was perceived also, that the students may develop a sense of belonging to this school and professors of history may encourage students becoming active involved with social affairs. The students' writing production also showed that students had developed high proficiency levels both in reading and writing.

In Universidad Nacional de Colombia, the history classes were organized as the social component of the program. Civilization I is the first history course for students in fifth semester. From sixth semester and up, students have an offer of more than fifteenth different history courses that included classes taught in English and German. The social component presented in the curriculum from Universidad Nacional de Colombia aims to encourage the students to be "social competent" and critical of their social environment. The class that was observed was a lecture on Contemporary History III, Europe since 1945. That lecture lasted three hours. The students were advised to read previous reading material and during the session, the students were actively engaged in class discussion.

The professor who taught the class observed was an English-native speaker who also helped the students with some complex topics related to history. It was necessary for the students who attended the class to have at least a B2 level; otherwise they could not perform accordingly. The written production expected from the course consisted in book reports and research papers.

\section{The Impact of Authentic Materials on Language Proficiency}

Language proficiency was one of the themes analyzed in this study. The reading material used in UNICA included Modern World History. Patterns of World Interaction (2012), The Story of America (2002), Inequality, Institutions 
and Economic Growth in Latin America, (2008), A Pocket Style Manual, (2004) and many other texts considered as real secondary sources. Since the classes are smaller, students had the opportunity to interact and discuss vocabulary and historical context. In Universidad Nacional de Colombia, some of the textbooks included in the history classes were; American Empire, The Realities and Consequences of U.S. Diplomacy, (2002), Entangled Empires of the Atlantic World, (2007) and Atlantic History. Concept and Contours, (2005).

These publications were not adapted for ELLs and the use of authentic material showed that students necessarily had to have certain advance knowledge of the language to understand the context of the readings. Using these publications helps expand the language skills and vocabulary of the students. In the case of Universidad Nacional de Colombia, the students had more autonomy but in many cases they were "on their own". The material used was very complex and the readings were more than plenty.

\section{Conclusions}

This research analyzed the methodology for the teaching of history that included CLIL and SIOP in UNNICA. In Universidad Nacional de Colombia the focus of the history courses was centered in the academics of history and the development of L2 languages skills. In general terms, the use of history classes as part of the curriculum for bilingual education programs may enrich the development of language skills both in L1 and L2. History classes both in UNICA and Universidad Nacional de Colombia helped to promote the building of the social context embedded in bilingual education. The use of history classes in terms of developing citizenship skills is positive and was evidenced in the interviews conducted by this study. In terms of achieving communicative goals, students that were using real historical material both with primary and secondary sources can get acquainted with advanced content skills both in L1 and L2.

The teaching of history also helped students developing language proficiency and motivation when learning a L2. Additionally, it was expected from the beginning of this study to observe a positive impact in students' development of social skills. Adding as well that education must bring all the elements required to the development of critical thinking inside and outside the classroom.

After the analysis of the data collected, the results confirmed this hypothesis, coinciding that bilingual students who had history classes in the curriculum might develop better global awareness, strong career skills and active citizenship not only in the education field. The mastery of key subjects and the development of $21^{\text {st }}$ skills might be the product of having History classes in bilingual programs. This assessment came after the review of the material that was produced by students from the schools that offered history classes in their programs.

In terms of cognitive development, this study identified the effective connection established between the students with the material used in class. The most of books used in ÚNICA contain timelines, graphics and illustrations that could motivate the students to research about the various topics presented in the curriculum; furthermore, it was also observed that most of the students already had a previous historical interest for the topic of the classes. Other material that was analyzed was the use of video and media historical production. In most cases the students were interested in the material and it helped the professor who used it, to motivate and make the concepts more visual to the students.

After the review of the class observation protocols from ÚNICA and Universidad Nacional de Colombia, it was concluded that students' oral skills were also benefitted due to the fact that students' oral skills were actively practiced during the history class sessions. Both written and oral fluency increased, and vocabulary expanded. History classes can be meaningful, interesting and joyful, the only things needed are strategies that engage students in this subject. History classes are important for the development of the student since they provide them with skills that they need to perform successfully in the $21^{\text {st }}$ century, for instance, collaboration, communication, critical thinking and creativity. This is known by the teachers but not by the students, and the main problem is that many students see the history subject as a senseless and boring class that does not relate to them. Hence, the teacher needs to create a class that mainly engage student in order to make understand the 
importance of history. In general, the use of authentic historical material motivated students to learn the language because they noticed they were facing academic challenges as part of the decoding input in the development of cognitive skills. The desire of the students to culturally interact with the sources was evident, as well as the possibility of learning about civilization and culture that was at first unfamiliar to them.

It is also important to highlight that the aim of including history content in bilingual programs can promote social awareness that is required in the understanding of politics, economics, and culture. The use of historical sources is recommended to further language skills toward fluency in the second language (Kareva-Echevarria, 2013, p. 240).

\section{Action Plan}

The use of history courses in Bilingual education requires the inclusion of various disciplines that can provide several alternatives and explanations to the same global issues. Adding as well, that higher education must bring all the elements required to the development of critical thinking inside and outside the classroom especially for language teachers. This study recognized that the inclusion of the social component represented in history classes was necessary to enrich any classroom experience.

Bilingual Education in Colombia needs to benefit from the use of history classes as a key element to understand social processes like the Colombian Peace Talks in Havana or how is going to affect the raising discontent that is striking Venezuela to the rest of Latin American nations. Nowadays, teachers have many tools and strategies that they can use in order to make their classes better. They have, for example, access to the Internet in which they can find videos, games, activities that they can try in their classes. Furthermore, teachers must show this tool to students so they can take advantage of it by doing something related to the class or the topic they are working with. Besides, although students might not have access to the Internet, the teacher can propose many activities and projects that students can enjoy and to develop better citizenship skills as well as language skills.

Understanding global relationships in Bilingual education requires not only the use of history classes, but also an interdisciplinary work that could include ethics; nevertheless, in order to reach a better understanding of the impact of using history classes in Bilingual education programs in Colombia, here we have some recommendations for researchers and schools administrators.

- Identify the type of history classes that could be taught in particular Bilingual programs.

- Step aside from the preconceptions of "history is not necessary for this program".

- In terms of building effective social skills. The interaction of several social disciplines can help to educate better citizens.

- Provide content material with the endless options that history can offer to build cognitive skills in future language teachers.

- Allow students to establish a genuine relationship with history in order to understand social issues that can be explained using effective language skills.

- Avoid boring history lessons that can support the misconception that history is just "memorization of unrelated data".

- Use several teaching techniques that can promote comprehension. The use of visual and multimedia material can foster the learning history in Bilingual education programs.

- History readings can fill the gap when language teachers need to include the social element pursuing better reading skills.

- Keep the students engaged with the endless possibilities that history can offer to enrich any Bilingual program. Field trips, scavenger's hunt, history contests can promote a rich learning experience for language learners 
In addition to the previous recommendations, the author of this article feels that it is necessary to explore other strategies that can also help developing social skills and a lasting interest for the history field. These strategies include two objectives. A content objective that can help improving the social component of the curriculum and a language objective that aims for a better proficiency both in L1 and L2.

Courses in History in bilingual education are a valuable component in building social skills, cultural appreciation and second language skills in undergraduate bilingual programs. The use of CLIL and SIOP models in History classes can also help to fortify language skills both in L1 and L1 while delivering content. These two methodologies are perhaps the most effective in bilingual programs based on the results of this study and the experience from the researcher as a history professor from ÚNICA and former student from Universidad Nacional de Colombia. The perception of the administrators from ÚNICA, Universidad Nacional de Colombia, and all the professors who teach history courses who were interviewed in this study was not only positive but indeed they all agree about the importance of using history as a key element in the curriculum.

\section{References}

Armstrong, T. (1995). Inteligencias múltiples en el salón de clases. Alexandria, VA: Association for Supervision and Curriculum Development.

Bartik, K. Maerten, C. Tudor, I. Valcke, J. (2009). A Discussion Brief of Content and Language Integrated Learning (clil) at the Faculty of Applied Sciences. Brussel: Université Libre de Bruxelles. 1-21

Canfora, Luciano. (2001). El misterio Tucídides. Madrid: Editorial Alderabán.

Cinganotto, Letizia. (2013). CLIL (Content and Language Integrated Learning): linguistic and interactional aspects. Rome: Università Degli Studi Roma Tre.

Coyle, Do. Hood, Philip. Marsh, David. (2010). Content and Language Integrated Learning. Cambridge: Cambridge University Press.

Dalton-Puffer, Cristiane. (2007) Discourse in Content and Language Integrated Learning (CLIL) Classrooms. Amsterdan: John Benjamins Publishing Co.

Diario Oficial 49522 de mayo 25 de 2015. Régimen Legal de Bogotá D.C. C Propiedad de la Secretaría General de la Alcaldía Mayor de Bogotá D.C. Decreto 1038 de 2015 Nivel Nacional

Duignan Bilingual Education: A Critique by Tuesday, September 1, 1998 The Struggle for Bilingual Education A Guide to Culture in the Classroom

Hawkey, Kate. Could You Just Tell Us the Story? Pedagogical Approaches to Introducing Narrative in History Classes. Curriculum Inquiry, Vol. 37, No. 3 (Sep., 2007), pp. 263-277

Hawkey, K. (2004). Narrative in classroom history. The CurriculumJournal, 15(1), 35-44.

Jong, E., \& Harper C. (2005). Preparing Mainstream Teachers for English-Language Learners: Is Being a Good Teacher Good Enough? Teacher Education Quarterly. Spring, 101-124

Kerpel, Mora, Jill, Joan Wink and Dawn Wink. Dueling Models of Dual Language Instruction: A Critical Review of the Literature and Program Implementation Guide. Bilingual Research Journal. 25: 4 Fall. 
Kim, H. (2009) The importance of bilingual education for language - minority children in the United States. Linguistic research 26 (3), 181-197

Krashen, Stephen (1982) Principles and Practice in Second Language Acquisition. Los Angeles:Pergamon Press.

Krashen, S. (1996). Under Attack: The Case Against Bilingual Education. Culver City, Calif.: Language Education Associates.

Leingang, Bradley (2014). Improving Reading Skills in Social Studies. Saint Catherine University.

Margana. (2009). Theoretical Justification of Bilingual Education Program in Indonesia Yakarta: State University of Yogyakarta. 772-784

McAndrew, M. (2003) School Spaces and the Construction of Ethnic Relations: Conceptual and Policy Debates. Toronto: Canadian Ethnic Studies. 2003, Vol. 35 Issue 2, p14-29

Nygren, Thomas (2011) UNESCO and Council of Europe Guidelines, and

History Education in Sweden, c. 1960-20021, Education Inquiry, 2:1, 37-60, DOI: 10.3402/ edui.v2i1.21961

Phillips, I (2008) Teaching History, London: SAGE

Saville-Troike, Muriel (1978). A Guide to Culture in the Classroom. Washington: National Institute.of Education. Pacific Policy Research Center. Successful Bilingual and Immersion Education Models/Programs. Honolulu: Kamehameha Schools, Research \& Evaluation Division. 2010.

Schermerhorn, R. A. (1970). Comparative Ethnic Relations. A Framework for Theory Research. New York: Random House.

Siegel, Micol (2005). Beyond Compare: Comparative Method After the Transnational Turn. Radical History Review. Winter 2005. 62-82

Szpara, Ahmad (2007). Supporting English-Language Learners in Social Studies Class Results from a Study of High School Teachers. The Social Studies, 98:5, 189-196

Portelli, Alessandro (1997). The Battle of Valle Giulia. Oral History and the Art of Dialogue. The University of Wisconsin Press.

Pokrivčáková, S. et al. (2015). CLIL in Foreign Language Education: e-textbook for foreign language teachers. Nitra: Constantine the Philosopher University. 7-16

Tilly, L. (2001). Interdisciplinary Contacts and Influences. Stearns, P. (Ed.), Encyclopedia of European Social History. From 1350 to 2000. Volume I. (pp. 60-69) New York: Charles Scribbers's Sons.

Werner, M.,Zimmermann, B. (2006). Beyond Comparison: Histoire Croisee and the Challenge of Reflexivity. Wesleyan University. 


\section{Appendix 1}

Questions for teachers and coordinators

\begin{tabular}{|c|c|}
\hline Question & Observations \\
\hline $\begin{array}{l}\text { 1. Is history as a subject included in the } \\
\text { curriculum? }\end{array}$ & \\
\hline $\begin{array}{l}\text { 2. The history of what period or region of the } \\
\text { world is included in your program? Why? }\end{array}$ & \\
\hline $\begin{array}{l}\text { 3. What type of history is included in your } \\
\text { program? }\end{array}$ & History Professor only \\
\hline $\begin{array}{l}\text { 4. What is the aim of using history classes in the } \\
\text { program? }\end{array}$ & \\
\hline $\begin{array}{l}\text { 5. Is history as a subject, a relevant aspect for } \\
\text { students that are pursuing a bilingual } \\
\text { career? Why? }\end{array}$ & \\
\hline $\begin{array}{l}\text { 6. As a subject, can history improve the } \\
\text { acquisition/development of English skills } \\
\text { in future bilingual educators? Why? }\end{array}$ & \\
\hline $\begin{array}{l}\text { 7. What should be the core of the history } \\
\text { element in a class for future bilingual } \\
\text { educators? }\end{array}$ & \\
\hline $\begin{array}{l}\text { 8. Is there is a different } \\
\text { approach/alternative/method you will like } \\
\text { to apply in your program, what that would } \\
\text { be? }\end{array}$ & \\
\hline $\begin{array}{l}\text { 9. Why don't you have a Colombian history } \\
\text { class in your program? }\end{array}$ & \\
\hline $\begin{array}{l}\text { 10. If you would include history classes in your } \\
\text { program, what would be the objective for } \\
\text { including them? }\end{array}$ & \\
\hline
\end{tabular}




\section{Appendix 2}

Check list in the observation protocol ${ }^{1}$

\begin{tabular}{|c|c|}
\hline Elements of the Observation & Observation \\
\hline $\begin{array}{l}\text { 1. The setting: } \\
\text { What is the physical environment like? } \\
\text { What is the context? } \\
\text { What kinds of behavior does the setting } \\
\text { promote or prevent? }\end{array}$ & \\
\hline $\begin{array}{l}\text { 2. The participants: } \\
\text { Describe who is in the scene, how many } \\
\text { people, and their roles. } \\
\text { What brings these people together? } \\
\text { Who is allowed here? }\end{array}$ & \\
\hline $\begin{array}{l}\text { 3. Activities and interactions: } \\
\text { What is going on? } \\
\text { Is there a definable sequence of activities? } \\
\text { How do the people interact with the } \\
\text { activity and with one another? } \\
\text { How are people and activities connected or } \\
\text { interrelated? }\end{array}$ & \\
\hline $\begin{array}{l}\text { 4. Frequency and } \\
\text { When did the situation begin? } \\
\text { How long does it last? } \\
\text { Is it a recurring type of situation or is it } \\
\text { unique? } \\
\text { If it recurs, how frequently? } \\
\text { How typical of such situations is the one } \\
\text { being observed? }\end{array}$ & \\
\hline $\begin{array}{l}\text { 5. Subtle factors: } \\
\text { Less obvious but perhaps as important to } \\
\text { the observation are: } \\
\text { - Informal and unplanned activities } \\
\text { - Symbolic and connotative meaning of } \\
\text { words } \\
\text { - Non verbal communication such as dress } \\
\text { - And physical space } \\
\text { - } \text { clues } \\
\text { What does not happen especially if it ought } \\
\text { to have happened. }\end{array}$ & \\
\hline
\end{tabular}

${ }^{1}$ Checklist by Merriam, S. B. (1988). Case study research in education: A qualitative approach. San Francisco: JosseyBass. 


\section{Appendix 3}

Check list to identify the key elements in documents ${ }^{2}$

\begin{tabular}{|c|c|}
\hline ITEM & Syllabus, lesson plans, P.E.I, and textbooks \\
\hline $\begin{array}{c}\text { All assessment questions regarding these } \\
\text { elements is enough to describe the data }\end{array}$ & \\
\hline Goals of data analysis are clearly written? & \\
\hline $\begin{array}{c}\text { Goals of data analysis are appropriate for the } \\
\text { general question? }\end{array}$ & \\
\hline $\begin{array}{c}\text { The specific analysis is appropriate for the main } \\
\text { research objective and the question or } \\
\text { purpose of the project. }\end{array}$ & \\
\hline $\begin{array}{c}\text { The format needed for results is described for } \\
\text { each specific analysis in the document } \\
\text { reviewed? }\end{array}$ & \\
\hline $\begin{array}{l}\text { Resources needed for each planned analysis } \\
\text { have been identified and a strategy for } \\
\text { obtaining those resources has been } \\
\text { developed. }\end{array}$ & \\
\hline
\end{tabular}

${ }^{2}$ Check list based on the document from https://www.ndsu.edu/fileadmin/vpsa.ndsu.edu/Assessment/Data_analysis_planning_checklist.pdf 


\section{Appendix 4}

Rubric for Poster

Rubric for Poster. 2017 Dr. Julio Bernal

\begin{tabular}{|c|c|c|c|c|c|}
\hline Category & $50-45$ & $44-40$ & $39-35$ & $34-30$ & $29-10$ \\
\hline Use of Class Time & $\begin{array}{l}\text { Used time well during } \\
\text { each class period. } \\
\text { Focused on getting the } \\
\text { project done. Never } \\
\text { distracted others. }\end{array}$ & $\begin{array}{l}\text { Used time well during } \\
\text { each class period. Usually } \\
\text { focused on getting the } \\
\text { project done and never } \\
\text { distracted others. }\end{array}$ & $\begin{array}{l}\text { Used some of the time well } \\
\text { during each class period. There } \\
\text { was some focus on getting the } \\
\text { project done but occasionally } \\
\text { distracted others. }\end{array}$ & $\begin{array}{l}\text { Did not use class time to focus } \\
\text { on the project or often } \\
\text { distracting others. }\end{array}$ & $\begin{array}{l}\text { The student did not do } \\
\text { any work during the } \\
\text { class }\end{array}$ \\
\hline Graphics -Clarity & $\begin{array}{l}\text { Graphics are all in } \\
\text { focus and the content } \\
\text { easily viewed and } \\
\text { identified from } 6 \mathrm{ft} \text {. } \\
\text { away. }\end{array}$ & $\begin{array}{l}\text { Most graphics are in } \\
\text { focus and the content } \\
\text { easily viewed and } \\
\text { identified from } 6 \mathrm{ft} \text {. away. }\end{array}$ & $\begin{array}{l}\text { Most graphics are in focus and } \\
\text { the content is easily viewed } \\
\text { and identified from } 4 \mathrm{ft} \text {. away. }\end{array}$ & $\begin{array}{l}\text { Many graphics are not clear } \\
\text { or are too small. }\end{array}$ & There are no graphics \\
\hline $\begin{array}{l}\text { Required } \\
\text { Elements }\end{array}$ & $\begin{array}{l}\text { The poster includes all } \\
5 \text { required elements as } \\
\text { well as additional } \\
\text { information. }\end{array}$ & $\begin{array}{l}\text { All } 5 \text { required elements } \\
\text { are included on the } \\
\text { poster. }\end{array}$ & $\begin{array}{l}\text { All but } 1 \text { of the required } \\
\text { elements are included on the } \\
\text { poster. }\end{array}$ & $\begin{array}{l}\text { Only } 3 \text { required elements are } \\
\text { in the poster. }\end{array}$ & $\begin{array}{l}\text { There is only one } \\
\text { requirement in the } \\
\text { poster. }\end{array}$ \\
\hline Attractiveness & $\begin{array}{l}\text { The poster is } \\
\text { exceptionally } \\
\text { attractive in terms of } \\
\text { design, layout, and } \\
\text { neatness. }\end{array}$ & $\begin{array}{l}\text { The poster is attractive in } \\
\text { terms of design, layout } \\
\text { and neatness. }\end{array}$ & $\begin{array}{l}\text { The poster is acceptably } \\
\text { attractive though it may be a } \\
\text { bit messy. }\end{array}$ & $\begin{array}{l}\text { The poster is distractingly } \\
\text { messy or very poorly } \\
\text { designed. It is not attractive. }\end{array}$ & $\begin{array}{l}\text { The colors are not } \\
\text { adequate for the poster. }\end{array}$ \\
\hline $\begin{array}{l}\text { Mechanics and } \\
\text { Grammar }\end{array}$ & $\begin{array}{l}\text { Capitalization and } \\
\text { punctuation and } \\
\text { grammar are correct } \\
\text { throughout the poster. }\end{array}$ & $\begin{array}{l}\text { There is } 1 \text { grammar } \\
\text { mistake on the poster. }\end{array}$ & $\begin{array}{l}\text { There are } 2 \text { grammar mistakes } \\
\text { on the poster. }\end{array}$ & $\begin{array}{l}\text { There are more than } 2 \\
\text { grammar mistakes on the } \\
\text { poster. }\end{array}$ & $\begin{array}{l}\text { There are more than } 5 \\
\text { mistakes on the poster }\end{array}$ \\
\hline Knowledge Gained & $\begin{array}{l}\text { Student can accurately } \\
\text { answer all questions } \\
\text { related to facts in the } \\
\text { poster and processes } \\
\text { used to create the } \\
\text { poster. }\end{array}$ & $\begin{array}{l}\text { Student can accurately } \\
\text { answer most questions } \\
\text { related to facts in the } \\
\text { poster and processes } \\
\text { used to create the poster. }\end{array}$ & $\begin{array}{l}\text { Student can accurately answer } \\
\text { about } 75 \% \text { of questions } \\
\text { related to facts in the poster } \\
\text { and processes used to create } \\
\text { the poster. }\end{array}$ & $\begin{array}{l}\text { Student appears to have } \\
\text { insufficient knowledge about } \\
\text { the facts or processes used in } \\
\text { the poster. }\end{array}$ & $\begin{array}{l}\text { The student cannot } \\
\text { answer any question } \\
\text { regarding to the poster. }\end{array}$ \\
\hline
\end{tabular}




\section{Appendix 5 \\ Rubric for report}

Rubric for Report. 2017 Dr. Julio Bernal

\begin{tabular}{|c|c|c|c|c|c|}
\hline Category & 50-45 & $44-40$ & 39-35 & $34-30$ & $29-10$ \\
\hline Position & $\begin{array}{l}\text { Includes } 3 \text { or more } \\
\text { pieces of evidence } \\
\text { (facts, statistics, } \\
\text { examples, real- life } \\
\text { experiences) that } \\
\text { support the position } \\
\text { statement. The writer } \\
\text { anticipates the } \\
\text { reader\'s concerns, } \\
\text { biases or arguments } \\
\text { and has provided at } \\
\text { least } 1 \text { counter- } \\
\text { argument. }\end{array}$ & $\begin{array}{l}\text { Includes } 3 \text { or more pieces } \\
\text { of evidence (facts, } \\
\text { statistics, examples, real- } \\
\text { life experiences) that } \\
\text { support the position } \\
\text { statement. }\end{array}$ & $\begin{array}{l}\text { Includes 2 pieces of evidence } \\
\text { (facts, statistics, examples, } \\
\text { real-life experiences) that } \\
\text { support the position } \\
\text { statement. }\end{array}$ & $\begin{array}{l}\text { Includes } 1 \text { or fewer pieces of } \\
\text { evidence (facts, statistics, } \\
\text { examples, real- life } \\
\text { experiences). }\end{array}$ & $\begin{array}{l}\text { There is no evidence at } \\
\text { all in the report. }\end{array}$ \\
\hline Sequencing & $\begin{array}{l}\text { Arguments and } \\
\text { support are provided } \\
\text { in a logical order that } \\
\text { makes it easy and } \\
\text { interesting to follow } \\
\text { the author \'s train of } \\
\text { thought. } \\
\end{array}$ & $\begin{array}{l}\text { Arguments and support } \\
\text { are provided in a fairly } \\
\text { logical order that makes } \\
\text { it reasonably easy to } \\
\text { follow the author 's train } \\
\text { of thought. }\end{array}$ & $\begin{array}{l}\text { A few of the support details or } \\
\text { arguments are not in an } \\
\text { expected or logical order, } \\
\text { distracting the reader and } \\
\text { making the essay seem a little } \\
\text { confusing. }\end{array}$ & $\begin{array}{l}\text { Many of the support details or } \\
\text { arguments are not in an } \\
\text { expected or logical order, } \\
\text { distracting the reader and } \\
\text { making the essay seem very } \\
\text { confusing. }\end{array}$ & $\begin{array}{l}\text { There are no arguments } \\
\text { that support the } \\
\text { writer's position. }\end{array}$ \\
\hline Attractiveness & $\begin{array}{l}\text { The poster is } \\
\text { exceptionally } \\
\text { attractive in terms of } \\
\text { design, layout, and } \\
\text { neatness. }\end{array}$ & $\begin{array}{l}\text { The poster is attractive in } \\
\text { terms of design, layout } \\
\text { and neatness. }\end{array}$ & $\begin{array}{l}\text { The poster is acceptably } \\
\text { attractive though it may be a } \\
\text { bit messy. }\end{array}$ & $\begin{array}{l}\text { The poster is distractingly } \\
\text { messy or very poorly } \\
\text { designed. It is not attractive. }\end{array}$ & $\begin{array}{l}\text { The colors are not } \\
\text { adequate for the poster. }\end{array}$ \\
\hline $\begin{array}{l}\text { Grammar \& } \\
\text { Spelling }\end{array}$ & $\begin{array}{l}\text { Author makes no } \\
\text { errors in grammar or } \\
\text { spelling that distract } \\
\text { the reader from the } \\
\text { content. }\end{array}$ & $\begin{array}{l}\text { Author makes } 1-2 \text { errors } \\
\text { in grammar or spelling } \\
\text { that distract the reader } \\
\text { from the content. }\end{array}$ & $\begin{array}{l}\text { Author makes } 3-4 \text { errors in } \\
\text { grammar or spelling that } \\
\text { distract the reader from the } \\
\text { content. }\end{array}$ & $\begin{array}{l}\text { Author makes more than } 4 \\
\text { errors in grammar or spelling } \\
\text { that distract the reader from } \\
\text { the content. }\end{array}$ & $\begin{array}{l}\text { Author makes more } \\
\text { than } 10 \text { errors in } \\
\text { grammar or spelling } \\
\text { that distract the reader } \\
\text { from the content. }\end{array}$ \\
\hline
\end{tabular}




\section{Appendix 6}

Unit of Study

Unit of Study Title: Introduction to Latin American Contemporary History Subject Area: History

Length of unit: Two Weeks

Brief description of unit: The main focus of this unit is that the students become aware of the uses of historical sources to understand present issues in Latin America.

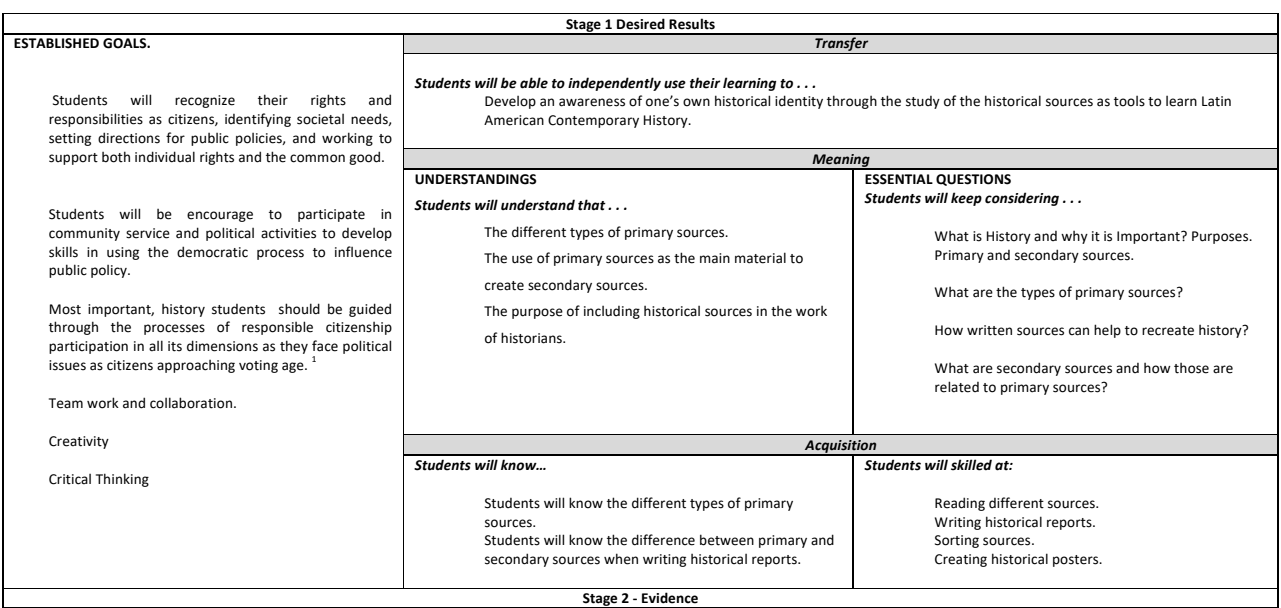




\section{Appendix 7 \\ Curriculum 2018. Única

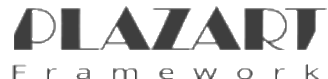

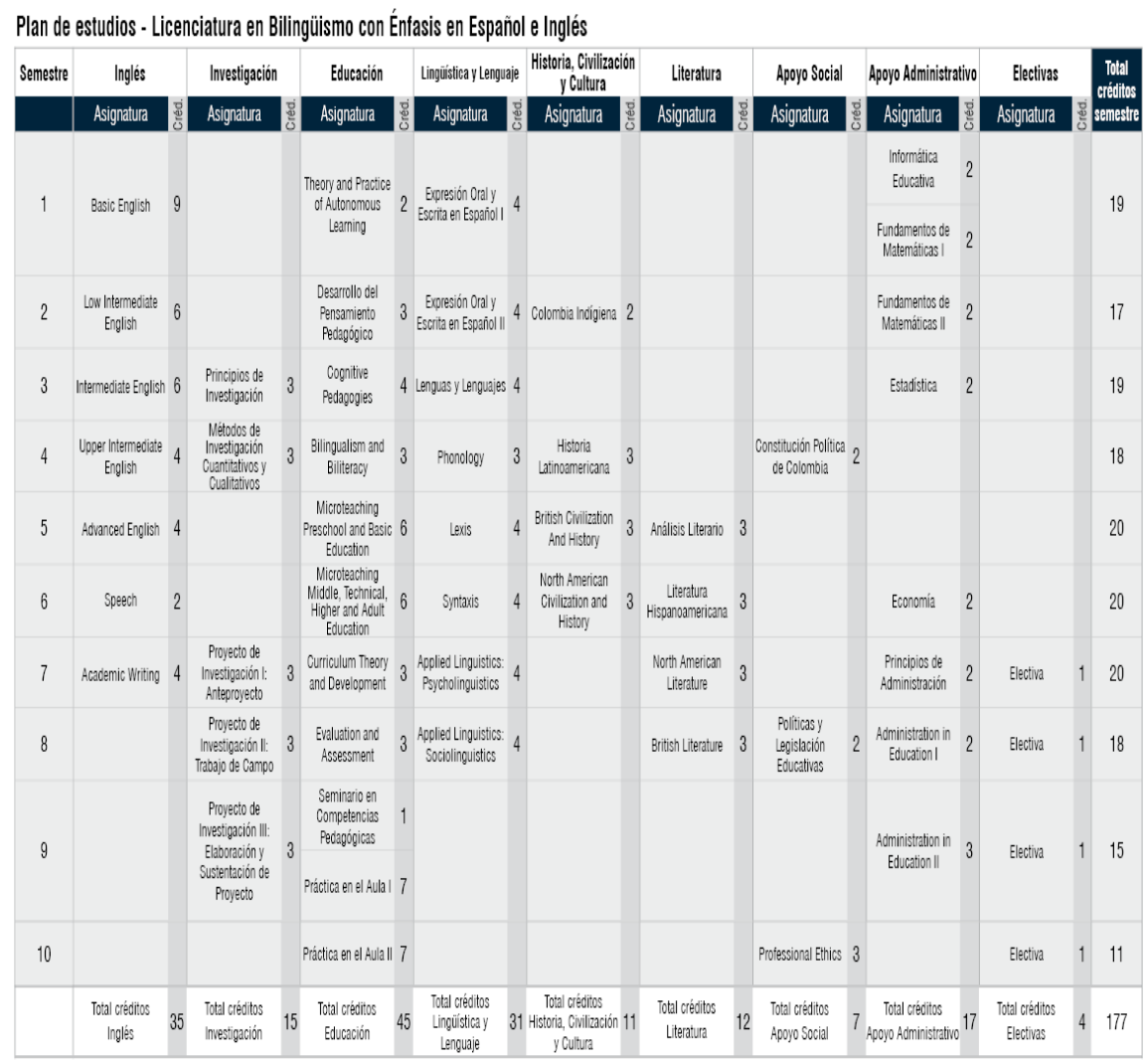

(c) Blank Plazart - Free Joomla! 3.0 Template (http://www.templaza.com) 2018 
Appendix 8

Curriculum 2018. Universidad Nacional de Colombia

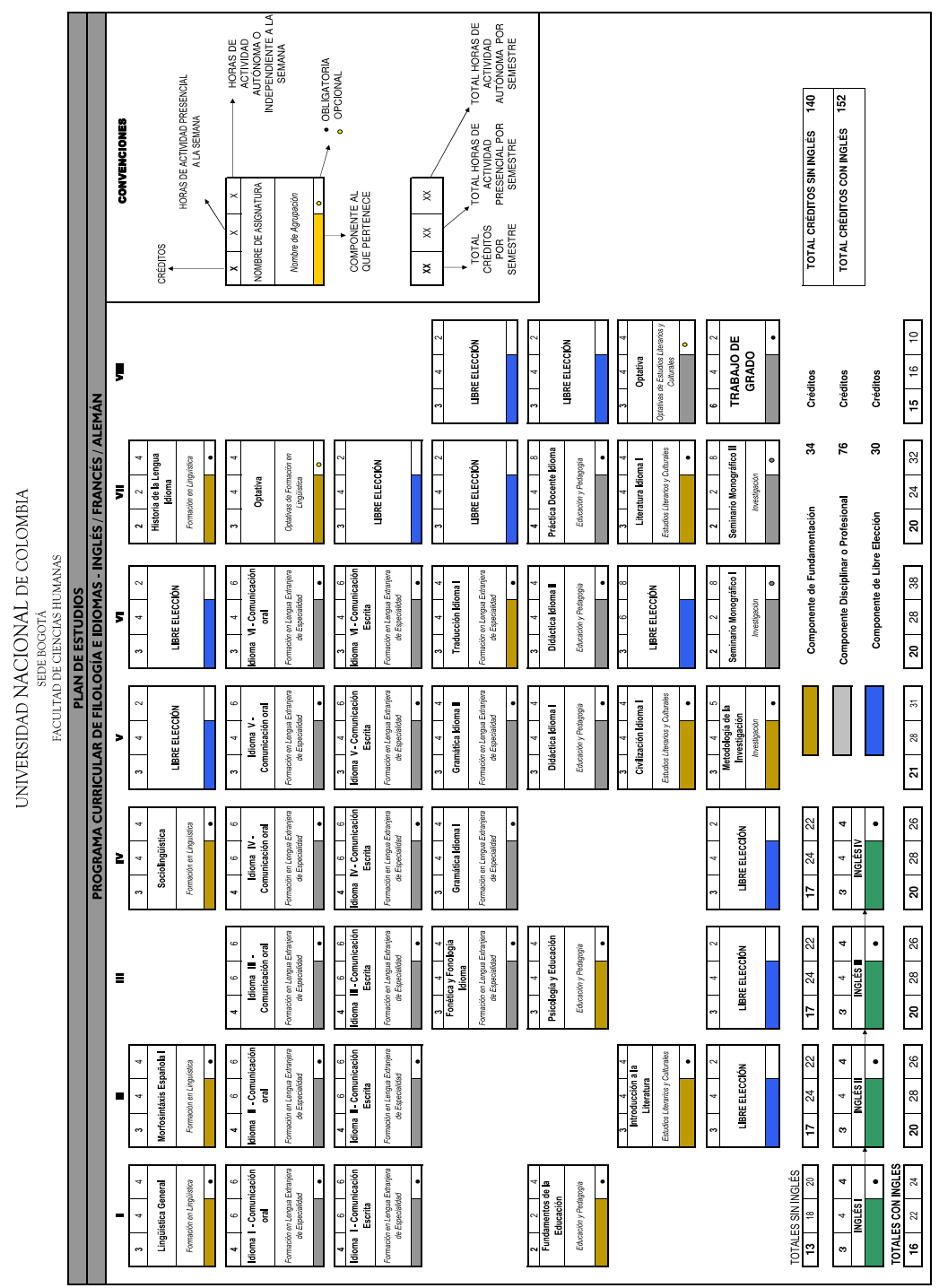


Appendix 9

Curriculum 2018. Universidad de la Salle

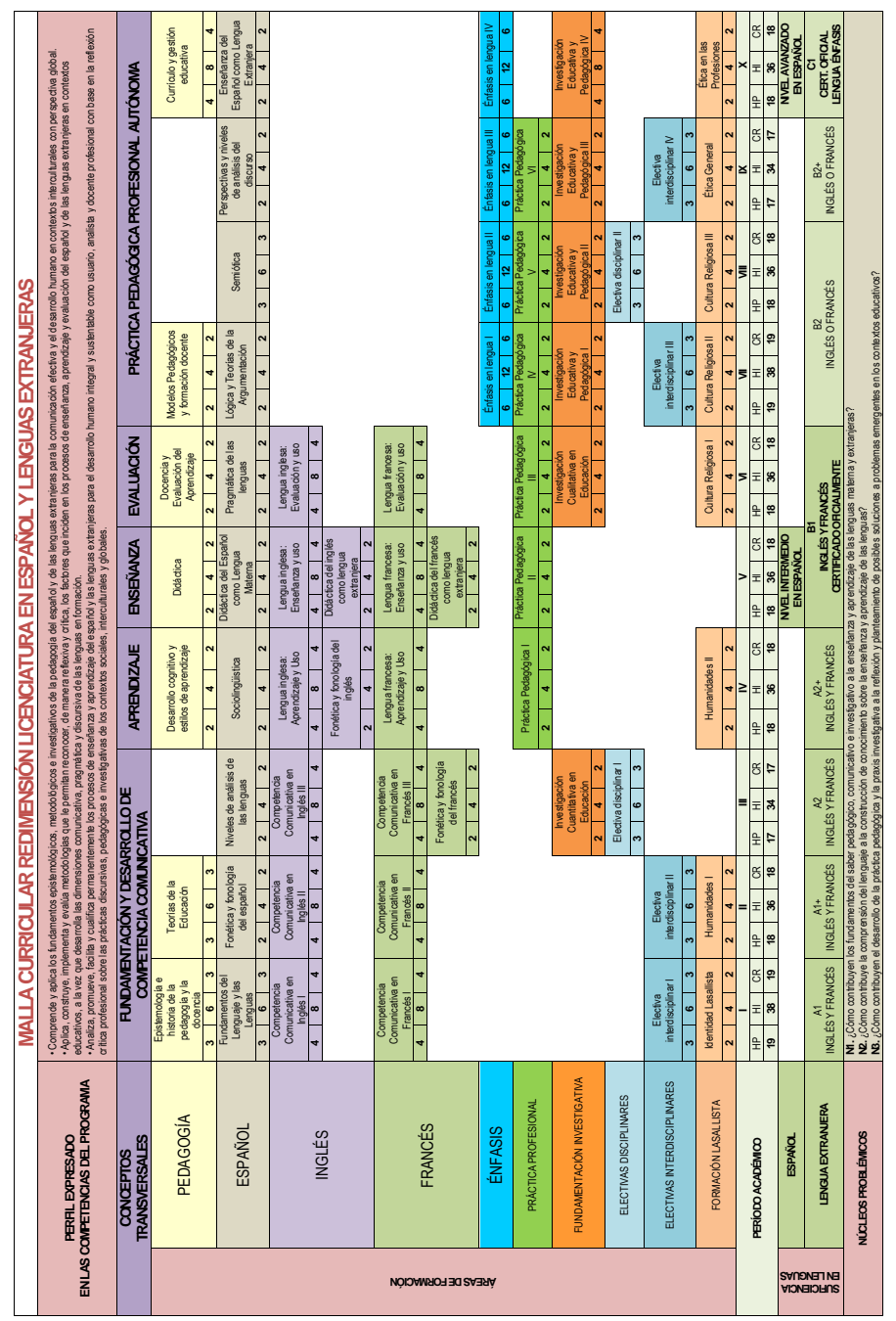

